\title{
Kontribusi Dana Desa dalam Pengembangan Badan Usaha Milik Desa di Desa Hanura, Kabupaten Pesawaran, Provinsi Lampung
}

\author{
Abdul Mutolib ${ }^{1 *}$, Dewangga Nikmatullah ${ }^{2}$, Irwan $_{\text {Effendi }}{ }^{3}$, Begem Viantimala ${ }^{4}$, dan Ali \\ Rahmat $^{5}$ \\ ${ }^{1,2,3,4}$ Program Studi Penyuluhan Pertanian, Fakultas Pertanian Universitas Lampung \\ ${ }^{5}$ The United Graduate School of Agricultural, Gifu University, Japan. \\ *amutolib24@yahoo.com
}

\begin{abstract}
One of the government's efforts to accelerate development in disadvantaged, deepest and outermost regions is through the Village Fund Policy. One of the obligations after the issuance of Law No. 6 of 2014 is the implementation of BUMDes (Village-Owned Enterprises). The study aims to analyze the contribution of Village Funds in the development of BUMDes in Hanura Village, Teluk Pandan District, Pesawaran District, Lampung Province. The study used a qualitative descriptive approach. Data collection was carried out through in-depth interviews with village officials and managers of BUMDes and field observations. The results of this study indicate that village funds in Hanura Village have contributed to the development of BUMDes. In 2018 the Hanura Village Government budgeted costs for the Procurement of Infrastructure Production Activities for Agriculture / livestock / fisheries production of Rp. 12,265,000.00. Then the Budget for Procurement of Marketing Infrastructure Activities (Shop and Cooperative Development) is Rp. 104,700,000.00, and the Community Economic Business Development and Establishment Activities (for other Capital Equipment and Machine Expenditures and animal and livestock capital expenditures) of Rp. 39,999,997.00. The business units owned by BUMDes Conscience include: 1) Market Management, 2) Product and Service Units, 3) Home Industry. One of the BUMDes marketing strategies is through online sales through the BUMDes website.
\end{abstract}

Keywords : Village fund, BUMDes, Hanura village

\begin{abstract}
Abstrak
Salah satu upaya pemerintah pusat dalam mempercepat pembangunan di wilayah tertinggal, terdalam dan terluar adalah melalui Kebijakan Dana Desa. Salah satu kewajiban pasca dikeluarkannya UU No 6 Tahun 2014 adalah implementasi BUMDes (Badan Usaha Milik Desa). Penelitian bertujuan untuk menganalisis kontribusi Dana Desa dalam pengembangan BUMDes di Desa Hanura, Kecamatan Teluk Pandan, Kabupaten Pesawaran, Provinsi Lampung. Penelitian menggunakan pendekatan deskriptifkualitatif. Pengumpulan data dilakukan melalui wawancara mendalam dengan aparat desa dan pengelola BUMDes dan observasi lapangan. Hasil penelitian ini menunjukkan bahwa dalam dana desa di Desa Hanura telah berkontribusi dalam pengembangan BUMDes. Pada tahun 2018 Pemerintah Desa Hanura menganggarkan biaya untuk Kegiatan Pengadaan Sarana Prasarana Produksi Usaha Pertanian/peternakan/perikanan sebesar Rp. 12.265.000,00. Kemudian Anggaran untuk Kegiatan Pengadaan Sarana Prasarana Pemasaran (Pembangunan pertokoan dan Koperasi) sebesar Rp. 104.700.000,00, dan Kegiatan Pendirian dan Pengembangan Usaha Ekonomi Masyarakat (untuk Belanja Modal Peralatan dan Mesin lainnya serta Belanja Modal Hewan dan Ternak) sebesar Rp. 39.999.997,00. Unit usaha yang dimiliki BUMDes Hati Nurani meliputi: 1) Pengelolaan Pasar, 2) Unit Produk dan Jasa, 3) Industri Rumah Tangga. Salah satu strategi pemasaran BUMDes adalah melalui penjualan secara online melalui website BUMDes.
\end{abstract}

Kata Kunci: Dana Desa, BUMDes, Desa Hanura 


\section{Pendahuluan}

\subsection{Latar Belakang}

Salah satu upaya pemerintah pusat dalam mempercepat pembangunan meningkatkan keterjangkauan pembangunan di wilayah tertinggal, terdalam dan terluar adalah melalui Kebijakan Dana Desa. Desa merupakan wilayah basis yang mana sebagian besar masyarakat Indonesai Tinggal, pembangunan pedesaan dianggap sebagai bentuk pembangunan yang bersifat bottom-up atau pembangunan partisipatif (Mustanir dan Abadi, 2017). Dalam pelaksanaan pembangunan, aspirasi masyarakat khususnya masyarkat desa merupakan syarat penting agar pembangunan dapat bejalan dengan baik (Sumbi dan Firdausi, 2016; Pusut, Kimbal, dan Mamntu, 2017). Dalam pembangunan pedesaa, masyarakat desa merupakan objek sekaligus objek yang partsisipasinya menjadi hal utama dalam mendukung pembangunan. Peranan pemerintah dalam pembangunan desa adalah sebagai fasilitator dan motivator. Pentingnya menjadikan masyarakat desa sebagai aktor utama pembangunan didukung bahwa sebagian besar masyarakat desa hidup dalam kemiskinan dan ketidakberdayaan (Nasar, 2016), sehingga perlunya mendorong masyarakat untuk mampu membangun dirinya sendiri dan keluar dari kemiskinan dan ketidakberdayaan.

Penetapan UU No. 6 Tahun 2014 tentang Desa memperkuat posisi Desa dalam kerangka Negara Kesatuan Republik Indonesia (NKRI). Penetapan undang-undang tersebut memperjelas tugas, peran dan fungsi desa dalam mengelola, memberikan pelayanan bagi masyarakat dan menjalankan pemerintahan desa demi mencapai kesejahteraan dan masyarakat yang berdaya (Kehik dan Mael, 2017; Jamaluddin dkk, 2018).

Salah satu kebijakan yang melatarbelakangi lahirnya UU Nomor 6 Tahun 2014 adalah kebijakan Dana Desa. Program Dana Desa, sebagaimana dijelaskan dalam Peraturan Pemerintah (PP) No 60 Tahun 2014 tentang Dana Desa yang menyatakan bahwa Dana Desa bersumber dari Anggaran Pendapatan dan Belanja Negara (APBN). Kebijakan Dana Desa diperuntukkan bagi desa melalui Anggaran Pendapatan dan Belanja Daerah (APBD) Kabupaten/Kota Dana Desa secara umum diperuntukkan dalam penyelenggaraan pemerintahan desa, pelaksanaan pembangunan, dan pembinaan serta pemberdayaan masyarakat (Atmojo dkk, 2017). Pada hakikatnya pertumbuhan ekonomi desa yang inklusif dan pemerataan pendapatan masyarakat desa merupakan tujuan umum program dana desa. Dana Desa yang jumlahnya mencapai milyaran rupiah memungkinkan desa melaksanakan berbagai program, pembangunan, pembinaan, dan pemberdayaan untuk mewujudkan masyarakat yang sejahteran dan mandiri (Kehik dan Mael, 2017).

Umumnya, permasalahan utama yang dihadapi dalam pembangunan pedesaan adalah rendahnya kualitas sumber daya manusia. Sebagian besar masyarakat dii pedesaan bekerja pada sektor pertania, dan sangat sedikit yang bekerja disektor lain (Tewu, 2015; Azlina dkk, 2017). Selain SDM, permasalahan lain yang dihadapi desa adalah keterbatasan sumber keuangan (Fossat, 2015; Meutia, dan Liliana, 2017). Salah satu upaya mempercepat perekonomian desa adalah, pemerintah mendorong desa mengembangkan suatu unit ekonomi yang berfungsi sebagai sumber penggerak perekonomian desa salah satunya melalui pendirian Badan Usaha Milik Desa (BUMDes) disetiap desa . Menurut Permendagri No 39 Tahun 2010, BUMDes merupakan usaha desa yang dibentuk/didirikan oleh pemerintah desa yang mana pengelolaan dan permodalannya menjadi tanggung jawab dan wewenang pemerintah dan juga masyarakat desa. Tujuan dari pendirian BUMDes adalah untuk meningkatkan kemampuan pemerintah desa dalam penyelenggaraan pemerintahan dan meningkatkan pendapatan masyarakat melalui usaha ekonomi masyarakat perdesaan. Pendirian BUMDes berlandaskan pada UU No. 6 Tahun 2014 dalam BAB X pasal 87-90 yang menjelaskan bahwa pendirian BUMDes disepakati melalui 
musyawarah desa dan dikelola dengan asas dan semangat kekeluargaan dan kegotong royongan (Prasetyo, 2016).

BUMDes memiliki dua fungsi utama dalam desa yaitu sebagai lebaga komersial dan lembaga sosial yang dimiliki desa. BUMDes sebagai sebagai lembaga komersial memiliki makna bahwa BUMDes bertujuan untuk memperoleh keuntungan melalui pemanfaatan sumberdaua lokal desa untuk meningkatkan pendapatan desa, kemudian sebagai lembaga sosial BUMDes memiliki peran dan berkontribusi sebagai penyedia pelayanan sosial masyarakat (Wijanarko, 2012).

Jenis usaha yang dikelola dan dikembangkan BUMDes telah diatur dalam Permen (Peraturan Menteri) yang meliputi usaha jasa, perdagangan hasil pertanian, penyaluran/distribusi bahan pokok dan industri rumah tangga skala kecil. Hal utama yang perlu menjadi catatan dalam pengembangan BUMDes adalah usaha harus berdasarkan potensi dan kebutuhan masyarakat desa. Perkembangan dan kemanjuan BUMDes tidak lepas dari dukungan pemerintah desa sebagai pemilik dBUMDes. Pemerintah Desa berperan dalam pengambangan BUMDes karena sejatinya BUMDes merupakan milik Pemerintahan desa yang kepemilikan modalnya harus sebagian besar dimiliki desa. Penyertaan modal BUMDes biasanya diambil dari Dana Desa, sehingga kebijakan Pemerintah Desa dalam alokasi Dana Desa untuk pengembangan BUMDes akan mempengaruhi sejauh mana kemajuan BUMDes. Semakin besar komitmen Pemerintaha Desa dan besaran Dana Desa yang dialokasikan untuk BUMDes akan besar pula potensi keberhasilan BUMDes dan sebaliknya.

\subsection{Permasalahan dan Tujuan}

Dari latar belakang penelitian, permasalahan yang akan dikaji meliputi bagaimana kontribusi Dana Desa dalam pengembangan BUMDes dalam upaya pembangunan dan pemberdayaan masyarakat Desa Hanura, Kec. Teluk Pandan, Kab. Pesawaran, Provinsi Lampung. Dari permasalahan penelitian tujuan penelitian ini meliputi:

1. Menganalisis kontribusi Dana Desa dalam pengembangan BUMDes di Desa Hanura

2. Mengidentifikasi unit usaha BUMDes di Desa Hanura, Kecamatan Teluk Pandan, Kabupaten Pesawaran.

\section{Metodologi}

\subsection{Jenis Penelitian}

Penelitian ini menggunakan pendekatan penelitiandeskriptif. Penelitian deskriptif merupakan penelitian yang mendeskripsikan atau menggambarkan suatu peristiwa atau kejadian secara sistematis, nyata dan akurat melalui pengungkapan fakta-fakta, sifat-sifat dari fenomena yang diamati (Moleong, 2013). Penelitian deskriptif adalah penelitian yang menggambarkan masyarakat atau kelompok dari karakteristik yang dimilikinya (Suehartono, 1995). Penelitian deskriptif dilakukan melalui metode survei literatur dan pengalaman. Survei literatur dalam peneliitian deskriptif bertujuan untuk memperoleh data primer, dan data sekunder. Ciri utama dari penelitian kualitatif adalah keterlibatan penelititi dalam seluruh proses penelitian. Dalam penelitian deskriptif, instrumen penelitian merupakan peneliti itu sendiri (Moleong, 2013).

\subsection{Informan Penelitian}

Penentuan informan penelitian menggunakan pendekatan purposive sampling yaitu teknik pengambilan sampel/informan dengan pertimbangan tertentu. Penentuam infoman dalam penelitian ini dengan mempertimbangkan tingkat pengetahuan informan. Informan yang dipilih merupkan orang-orang yang dianggap paling mengetahui informasi yang dibutuhkan dalam 
penelitian atau yang bersangkutan berkedudukan sebagai penguasa sehingga akan memudahkan peneliti dalam menjelajahi obyek atau situasi sosial yang dijadikan fokus penelitian (Sugiyono, 2013). Informan penelitian ini berjumlah 16 informan dengan rincian 4 (empat) informan berasal Aparatur Desa, 6 (enam) informan berasl dari Pengurus BUMDes, dan 6 (enam) informan berasal dari masyarakat yang mendukung dan berpartisipasi dalam pengembangan BUMDes.

1. Pemerintah Desa. Pemerintah Desa sebagai pemilik modal dan pihak yang paling berperan dalam pembentukan BUMDes.

2. Pengelola BUMDes. Pengelola BUMDes merupakan orang-orang berkecimpung dalam pengelolaan BUMDes sehingga memahami segala hal yang berkaitan dengan pengelolaan BUMDes

3. Masyarakat Desa Hanura yang berpartisipasi dalam pengembangan BUMDes, misalkan membeli barang/jasa yang dikelola BUMDes, menyertakan modal, dan lain sebagainya.

\subsection{Metode pengumpulan Data}

Penulis menggunakan teknik interview dengan pedoman wawancara terbuka dan semi terbuka. Interview bertujuan untuk memperoleh informasi yang terpercaya dan faktual. Dalam penelitian ini dilakukan triangulasi informan yang mana membandingkan informasi terkait BUMDes dari berbagai informan. Selain metode interview, penulis menggunakan pendekatan observasi atau pengamatan untuk mengumpulkan data. Observasi adalah sebuah proses pengamatan fenomena dilapangan oleh peneliti menggunakan panca indera dan tidak mengajukan pertanyaan-pertanyaan (Soehartono, 2008). Dalam penelitian ini, digunakan observasi nonpartisipan yang artinya observer tidak turut serta dalam kehidupan dan rutinitas informan atau pihak yang sedang diobservasi (Narbuko dan Achmadi, 1997).

\subsection{Analisis Data}

Analisis data yang digunakan bersifat deduktif yaitu berfikir secara Makro-Mikro atau mengurutkan masalah dari permasalahan umum lalu mengerucutkan ke masalah yang lebih kecil. Hal ini dilakukan untuk memudahkan melihat akar permasalahan dalam kajian penelitian yang diambil. Analisis data menggunakan pendekatan analisis data interaktif yang dimulai dari pengumpulan data kemudian selanjutnya dibagi dalam 3 (tiga) tahapan yaitu: 1) reduksi data, 2) penyajian data, dan 3) penarikan kesimpulan (Miles dan Huberman, 2009).

\section{Hasil dan Pembahasan}

\subsection{Gambaran Umum BUMDes Hati Nurani}

Sebagai upaya meningkatan pendapatan dan perekonomian desa dalam mendukung pemerintahan dan pembangunan, Pemerintah Desa Hanura telah menidirikan BUMDes melalui Peraturan Desa (Perdes) Nomor 4 Tahun 2015. BUMDes didirikan sebagai keajiban atas kebijakan Dana Desa, meningkatkan Pendapatan Asli Desa (PADes), serta menumbuhkan perekonomian desa. BUMDes di Desa terdiri dari Unit-unit usaha masing-masing. Tugas pengelola atau pengurus BUMDes ialah melaporkan kemajuan perkembangan kepada Badan Pengawas/Komisaris dan Pemerintah Desa Hanura. BUMDes di Desa Habura dibentuk dan ditetapkan pada tanggal 24 April 2015.

Tujuan dari pendirian/pembentukan BUMDes Desa Hanura meliputi :

a. Meningkatkan PAD dalam rangka meningkatkan kemampuan Pemerintah Desa dalam penyelenggaraan Pemerintahan dan Pelayanan masyarakat di Desa Hanura 
b. Mendorong tumbuhnya perekonomian masyarakat Desa dalam rangka pengentasanan kemiskinan dan kesejahteraan melalui pengembangan potensi lokal desa.

c. Menciptakan kesempatan kerja baru (lapangan kerja) serta menyediakan jaminan sosial bagi masyarakat Desa Hanura.

Tabel 1. Kepengurusan BUMDes Hati Nurani, Desa Hanura Provinsi Lampung

\begin{tabular}{lll}
\hline No.Nama & Jabatan dalam masyarakat & Kedudukan dalam BUMDes \\
\hline 1. Chodri cahyadi & Kepala Desa & Komisaris \\
2. Zikri septiawan & Masyarakat & Ketua \\
3. Deshita & Kaur Umum Desa & Sekretaris \\
4. Eka Damayanti & Masyarakat & Bendahara \\
& & Koordinator Unit Usaha \\
5. Hajuli & Masyarakat & Penggelolaan Pasar \\
& & Koordinator Unit Usaha \\
& & Rumah Tangga (Produk/Jasa \\
6. Herman & Masyarakat & dan Industru Rumah tangga) \\
\hline
\end{tabular}

Sumber : Profil BUMDes Desa Hanura, 2018

\subsection{Peranan Dana Desa dan Pengembangan Ekonomi BUMDes Hanura}

UU No. 6 Tahun 2014 Pasal 1 Ayat 1 menjelaskan bahwa desa adalah kesatuan masyarakat hukum yang memiliki batas wilayah serta memiliki wewenang dalam mengatur urusan pemerintahan dan kepentingan masyarakat berdasarkan prakarsa masyarakat, hak asal usul, dan/atau hak tradisional yang diakui dan dihormati dalam sistem pemerintahan NKRI. Oleh karena itu Desa perlu memperoleh perhatian dari pemerintah pusat secara seius, karena pada hakikatnya kemajuan bangsa dan Negara berawal dari pembangunan pedesaan yang baik dan merata. Berdasarkan pasal 78, Pembangunan Desa sesuai bertujuan untuk meningkatkan kesejahteraan dan kualitas hidup masyarakat desaa untuk mencukupi kebutuhan dasar dan mengatasi kemisikinan, pengembangan potensi lokal, sarana prasarana dan pemanfaatan sumber daya alam dan lingkungan secara bijaksana dan berkelanjutan.

Seiring berjalannya waktu, Desa telah menjadi prioritas utama dalam pembangunan baik bidang infrastruktur maupun non-infrastruktur. Pembangunan desa saat ini diarahkan melalui optimalisasi potensi desa. Bentuk lain dari kepedulian pemerintah pusat dalam pembangunan pedesaan untuk meningkatkan kesejahteraan masyarakat desa adalah melalui kebijakan Dana Desa. Lahirnya kebijakan Dana Desa telah mendorong pemerintah dalam upaya peningkatan kesejahteraan dan pengentasan kemiskinan masyarakat desa melalui kebijakan pembentukan dan pengembangan BUMDes di setiap desa. BUMDes juga hadir sebagai upaya pemerintah pusat dalam mengatasi masalah perekonomian masyarakat desa yang umumnya memiliki pendapatan rendah, dan hidup dibawah garis kemiskinan. Selain itu BUMDes didririkan sebagai upaya untuk memobilisasi pengelolaan asset desa serta membantu dan mendukung usaha kecil yang berkembang dalam masyarakat.

Menurut Permendagri Nomor 39 Tahun 2010 Tentang BUMDes (Pasal 1 ayat 6), BUMDes adalah usaha Desa yang didirikan/dibentuk oleh pemerintah desa yang pengelolaannya dilakukan oleh pemerintah desa dan masyarakat serta kepemilikan modal modalnya dimiliki sebagaian besar oleh desa. Salah satu desa Kabupaten Pesawaran yang memiliki BUMDes adalah Desa Hanura Kec. Teluk Pandan Kabupaten Pesawaran dengan nama BUMDes Hanura.

BUMDes Desa Hanura merupakan BUMDes yang aktif dan memiliki prospek ekonomi yang menguntungkan. Dalam dua tahun terakhir, telah banyak kemajuan yang dicapai BUMDes Hati Nurani. Pada tahun 2018 Pemerintah Desa Hanura menganggarkan biaya untuk Kegiatan 
Pengadaan Sarana Prasarana Produksi Usaha Pertanian/peternakan/perikanan sebesar Rp. 12.265.000,00. Kemudian Anggaran untuk Kegiatan Pengadaan Sarana Prasarana Pemasaran (Pembangunan pertokoan dan Koperasi) sebesar Rp. 104.700.000,00, dan Kegiatan Pendirian dan Pengembangan Usaha Ekonomi Masyarakat (diperuntukkan Belanja Modal Peralatan dan Mesin lainnya serta Belanja Modal Hewan dan Ternak) sebesar Rp. 39.999.997,00.

Pemanfaatan Dana Desa di Desa Hanura dalam beberapa tahun terakhir masih diprioritaskan ke sektor infrastruktur. Meskipun demikin, aparatur pemerintahan Desa Hanura mempunyai komitmen dalam mengembangkan BUMDes Hati Nurani. BUMDes Hati Nurani merupakan bentuk nyata kontribusi Dana Desa dalam pengembangan ekonomi desa melalui pendirian dan penguatan kelembagaan BUMDes. Sejauh ini pengembangan BUMDes di Desa Hanura memang belum terlalu terlihat peranannya dalam kemajuan ekonomi desa diwaktu dekat, meskipun demikian dimasa mendatang Hanura berpotensi memiiki BUMDes yang kuat dan berkontribusi dalam pengembangan ekonomi desa melalui BUMDes.

\subsection{Unit Usaha BUMDes Hati Nurani Desa Hanura}

Program Dana Desa telah berkontribusi besar di berbagai aspek termasuk pengembangan ekonomi masyarakat melalui BUMDes. Beberapa bentuk pengembangan usaha yang dilakukan oleh BUMDes Hati Nurani dengan sumber keuangan dari Dana Desa meliputi usaha: 1) Pengelolaan pasar, 2) Unit produk dan jasa, 3) Industri rumah tangga. Usaha yang dirintis BUMDes Hati Nurani mengalami kemajuan yang signifikan. Kemajuan BUMDes Hati Nurani tidak terlepas dari kontribusi program Dana Desa yang mendukung secara penuh kebutuhan BUMDes Hati Nurani.

\subsubsection{Unit Pengelolaan Pasar}

Salah satu Unit Usahan BUMDes Hati Nurani adalah Unit Pengelolaan Pasar. Di Desa Hanura terdapat Pasar Ampera yang merupakan pusat kegiatan ekonomi masyarakat. Pasar Ampera merupakan salah satu tumpuan masyarakat dalam kegiatan ekonomi di Desa Hanura. Keberadaan pasar merupakan sebuah potensi yang apabila dapat dimanfaatkan dengan baik oleh BUMDes akan dapat memeberikan keuntungan yang besar. Kegiatan perekonomian yang dikelola BUMDes Hati Nurani di Pasar Ampera Desa Hanura meliputi 2 (dua) kegiatan yaitu usaha pengelolaan sampah dan parkir. Unit usaha Pengelolaan sampah dan parkir memberikan pemasukan terbesar bagi BUMDes dan Desa.

Meskipun telah menjadi sektor unggulan di Desa Hanura, Unit usaha Pengelolaan sampah dan parkir perlu ditingkatkan pengelolaannya. Selain peningkatan pengelolaan dalam upaya meningkatkan retribusi/pendapatan, kedua usaha ini sudah seharusnya dapat bermanfaat bagi masyarakat luas. Pengelolaan sampah yang baik merupakan suatu hal yang mutlak dalam mengatasi sampah yang menumpuk baik sampah rumah tangga dan sampah lainnya. Kedepan, pengelolaan pasar di Desa Hanura yang dikelola BUMDes Hati Nurani harus melibatkan masyarakat, setempat, hal ini sebagai upaya menciptakan lapangan kerja dan pemberdayaan bagi masyarakat khususnya masyarakat yang tidak mampu atau masih menganggur. Sejauh ini keberadaan BUMDes Hati Nurani telah dapat memberikan kontribusi dalam pengelolaan pasar di Desa Hanura dan memberikan sumbangan pendapatan bagi desa.

\subsubsection{Unit Usaha Jasa}

Hasil interview dengan Ketua BUMDes Hati Nurani (Bapak Zikri) bahwa pada hakikatnya produk yang dijual oleh BUMDes Hati Nurani adalahjasa. Usaha jasa yang disediakan BUMDes Hati Nurani meliputi jasa renting, jasa loket pembayaran listrik, jasa konter 
(servis HP) dan lainnya. Pengelola BUMDes Hati Nurani menilai bahwa usaha jasa lebih menguntungkan dan menjanjikan dibandingkan usaha produk atau barang, sehingga usaha jasa menjadi salah satu unit unggulan di BUMDes Hati Nurani.

Saat ini, Unit Usaha Jasa yang BUMDes Hati Nurani dinilai masih kurang perkembangannya dibandingkan Unit Usaha Pengelolaan Sampah dan Parkir. Unit Usaha jasa langsung ditangani oleh pengurus BUMDes yang juga berperan sebagai aparat desa, kondisi ini telah menimbulkan kecemburuan sosial di kalangan masyarakat yang menilai terdapat pihakpihak yang memanfaatkan BUMDes untuk kentungan pribadi. Hal ini menjadi catatan penting dimasa yang akan datang bahwa pengelolaan bumdes harus netral dan menjungjung tinggi kketerbukaan sehingga tidka muncul kecemburuan sosial, selain itu kegiatan peroekonomian BUMDes harus dapat meningkatkan peerekonomian, menciptakan lapangan kerja dan mengedepankan kepentingan dan kebutuhan masyarakat desa.

\subsubsection{Industri Rumah Tangga Kelompok Wanita Tani}

Salah satu Unit Usaha yang dimiliki BUMDes Hati Nurani adalah Unit Usaha Industri Rumah Tangga. Unit Usaha ini dikelola BUMDes Hati Nurani yang bekerjasama dengan Kelompok Wanita Tani (KWT). KWT di Desa Hanura merupakan kelompok Ibu-ibu yang melakukan pemberdayaan dan peningkatan perekonomian keluarga melalui pembuatan produk/industry rumahan dari bahan lokal yang tersedia di desa. Sebelum adanya BUMDes, anggota KWT telah menghasilkan produk dan barangnya dititipkan di warung-warung yang ada di desa, namum produk kurang diminati masyarakat. keberadaan BUMDes telah membantu pemasaran produk yang dihasilkan anggota KWT.

Produk andalan yang dihasilkan oleh KWT dan BUMDes Hati Nurani adalah keripik tempe sagu dan sirup belimbing wuluh. Kedua produk ini saat ini telah menjadi produk unggulan Desa Hanura. Peranan BUMDes dalam hal ini adalah sebagai jembatan pemasaran bagi produk yang dihasilkan masyarakat kususnya anggota KWT, Dan BUMDes tidak memperoduksi produk. Produk hasil indusstri rumah tangga yang dihasilkan masyarajat (anggota KWT) menjadi produk BUMDes, $85 \%$ dari hasil penjualan dikembalikan kepada masyarakat/anggota KWT yang memproduksi produk tersebut.

Usaha yang dikelola oleh BUMDes Hati Nurani secara umum telah mampu meningkatkan pendapatan dan perekonomian masyarakat. Melalui usaha yang dikembangkan BUMDes, telah tercipta lapangan kerja baru dan menjadi wadah pemasaran produk yang dihasilkan masyarakat. Hasil keuntungan yang diperoleh BUMDes diberikan kepada desa sesuai dengan kesepakatan/atau aturan yang ditetapkan dalam PERDES dan Anggaran Dasar/Anggaran Rumah Tangga (AD-ART) BUMDes.

\subsection{Toko Online BUMDes Hati Nurani}

Sebagai upaya meningkatkan kinerja, BUMDes Hati Nurani Desa Hanura telah bekerjasama dengan Pemerintahan Desa Hanura. Kerjasama yang terjalin antara BUMDes dan Pemerintahan desa bertujuan untuk meningkatkan pemasaran produk dan jasa yang dimiliki BUMDes Hati Nurani. Kerjasama yang terjalin adalah melalui prosmosi penjualan produk dan jasa BUMDes melalui website desa: http://hanura.desa.id/. BUMDes Hati Nurani telah memiliki website untuk memasarkan produk BUMDes yang dapat diakes melalui: http://bumdes.desahanura.com/.

Beberapa produk yang dijual di toko online BUMDes Hati Nurani meliputi aneka olahan keripik pisang, keripik tempe, kerajinan dari limbah kayu, serta kerjinan tas rajut. BUMDes Hati Nurani Desa Hanura telah bermitra dengan Garuda Dellivery dan Bank BNI 46 Cabang Tanjung Karang dalam pengembangan BUMDes melalui kegiatan CSR perusahaan dan memanfaatkan 
kemajuan teknologi informasi untuk meningkatkan penjualan melalui pemanfaatan email, WA, dan media online lainya. Pemanfaatan teknologi informasi oleh BUMDes Hati Nurani merupakan upaya untuk meningkatkan penjualan hasil produk BUMDes Hati Nurani. Penggunaan media sosial untuk pemasaran produk BUMDes Hati Nurani selaras dengan kemajuan zaman untuk mendukung keberhasilan usaha yang dirintis oleh BUMDes Hati Nurani.

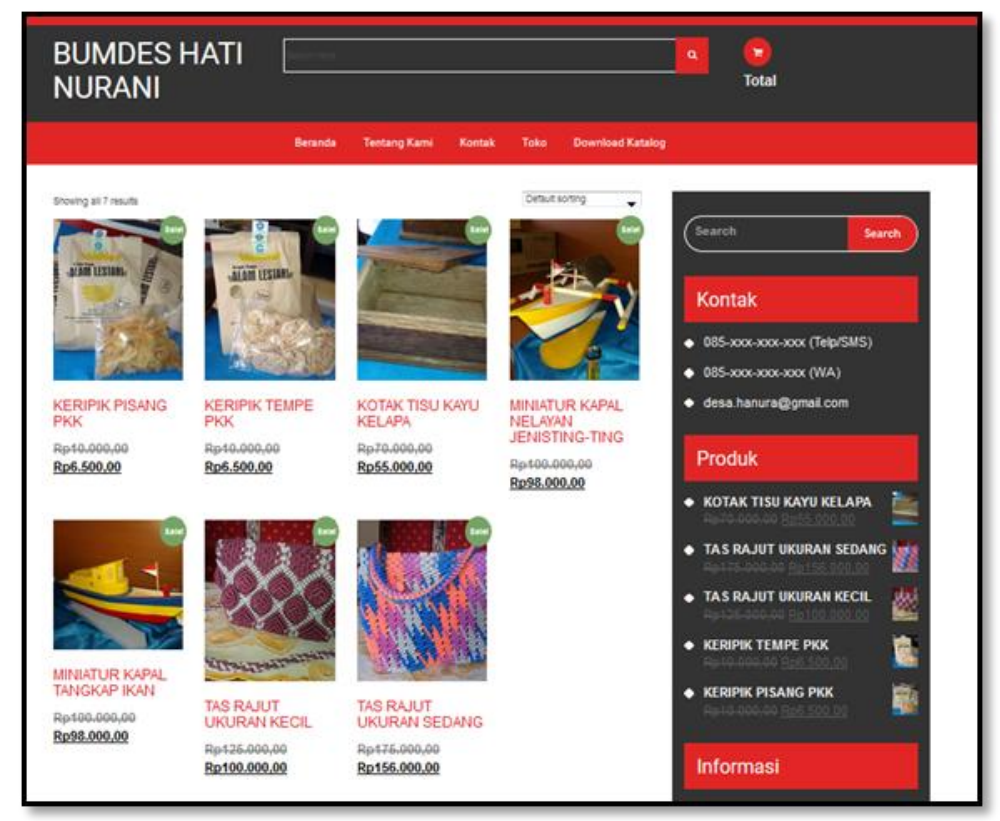

Gambar 1. Toko Online BUMDes Hati Nurani Desa Hanura

\section{Kesimpulan}

Program Dana Desa di Desa Hanura telah berkontribusi dalam pengembangan BUMDes. Pada tahun 2018 Pemerintah Desa Hanura menganggarkan biaya untuk Kegiatan Pengadaan Sarana Prasarana Produksi Usaha Pertanian/peternakan/perikanan sebesar Rp. 12.265.000,00. Kemudian Anggaran untuk Kegiatan Pengadaan Sarana Prasarana Pemasaran (Pembangunan pertokoan dan Koperasi) sebesar Rp. 104.700.000,00, dan Kegiatan Pendirian dan Pengembangan Usaha Ekonomi Masyarakat (untuk belanja modal peralatan, mesin usaha, serta belanja modal hewan dan ternak) sebesar Rp. 39.999.997,00. Unit usaha yang dimiliki BUMDes Hati Nurani meliputi: 1) Pengelolaan Pasar (BUMDes Hati Nurani mengelola 2 (dua) unit usaha yaitu pengelolaan sampah dan parkir), 2) Unit Produk dan Jasa (Jasa renting, jasa loket, jasa konter (servis HP), 3) Industri Rumah Tangga (BUMDes bekerja sama dan membantu pemasaran produk hasil kerajinan dan makanan yang dimiliki Kelompok Wanita Tani di Desa Hanura). Salah satu strategi pemasaran BUMDes adalah melalui penjualan online di website BUMDes Hati Nurani.

\section{Saran}

Secara umum pengelolaan Dana Desa di Desa Hanura Kecamatan Teluk Pandan Kabupaten Pesawaran telah berkontribusi dalam pengembangan BUMDes Hati Nurani. BUMDes Hati Nurani merupakan BUMDes yang aktif dan saat ini sedang berkembang. Perlunya pendampingan baik dari pihak pemerintah, swasta, perguruan tinggi dalam mendukung kemajuan BUMDes Hati Nurani. Permasalahan utama yang dihadapi BUMDes Hati Nurani adalah terkait 
pemasaran produk rumah tangga dan kerajinan. Dukungan dari stakeholders terkait akan mendukung dalam kemajuan BUMDes Hati Nurani Desa Hanura.

\section{Daftar Pustaka}

Atmojo, M.E., Fridayani, H.D., Kasiwi, A.N dan Pratama, M.A. 2017. Efektivitas dana desa untuk pengembangan potensi ekonomi berbasis partisipasi masyarakat di Desa Bangunjiwo. Sosial Politik Humaniora, 5(1): 126-140. Downloaded from: http://journal.umpo.ac.id/index.php/aristo/article/view/423.

Azlina, N., Hasan, A., Desmiyawati., dan Muda, I. 2017. The Effectiveness of Village Fund Management (Case Study at Villages in Coastal Areas in Riau. International Journal of Economic Research, 14 (12): 325-336.

Chasanah,K., Rosyadi, S., dan Kurniasih, D. 2017. Implementasi Kebijakan Dana Desa. IJPAThe Indonesian Journal of Public Administration, 3 (2): 12-31. Downloaded from: http://journal.uta45jakarta.ac.id/index.php/admpublik/index

Fossati, D. 2016. Beyond "Good Governance" : The Multi-level Politics of Health Insurance for the Poor in Indonesia. World Development, 87, 291306. https://doi.org/10.1016/j.worlddev.2016.06.020.

Jamaluddin, Y., Sumaryana, A., Rusli, B \& Buchari, R.A. 2018. Analisis Dampak Pengelolaan dan Penggunaan Dana Desa terhadap Pembangunan Daerah. JPPUMA: Jurnal Ilmu Pemerintahan dan Sosial Politik UMA, 6 (1) (2018): 14-24. Downloaded from: http://ojs.uma.ac.id/index.php/jppuma/article/download/1520/pdf2.

Kehik, B.S. dan Mael, M.Y. 2017. Analisis Pengelolaan Alokasi DD (Dana Desa) dalam Peningkatan Perekonomian Masyarakat Petani di Desa Usapinonot. Agrimor 2(4): 5962.

Meutia, I dan Liliana. 2017. Pengelolaan Keuangan Dana Desa. Jamal: Jurnal Akuntansi Multiparadigma, 8 (2): 226-352. Downloaded from: http://jamal.ub.ac.id/index.php/jamal/article/view/645.

Miles, Matthew B. \& A. Michael Huberman. 2009. Analisis Data Kualitatif. Jakarta: Universitas Indonesia-Press.

Moleong, L. J. 2013. Metode Penelitian Kualitatif. Bandung: PT Remaja Rosdakarya.

Narbuko, C dan Achmadi, A. 1997. Metodologi Penelitian. Jakarta: Bumi Aksara.

Nasar, M. 2016. Program Alokasi Dana Desa (ADD) dalamPengembangan Ekonomi di Kecamatan Marawola Kabupaten Sigi. E-Jurnal Katalogis, 4(12): 56-63.

Prasetyo, R.A. 2016. Peranan Badan usaha Milik Desa (BUMDes) dalam Pembangunan Dan Pemberdayaan Masyarakat Di Desa Pejambon Kec. Sumberejo Kab. Bojonegoro. Jurnal Dialektika, 11 (1): 86-100.

Pusut, R., Kimbal, M., dan Mamentu, M. 2017. Pembangunan Berbasis Pemberdayaan Masyarakat di Desa Pasir Putih Kec. Pamona Selatan Kab. Poso. Jurnal Jurusan Ilmu Pemerintahan, 2(2): 1-18: Downladed from: https://ejournal.unsrat.ac.id/index.php/jurnaleksekutif/article/view/18309/17838.

Soehartono, I. 2008. Metode Penelitian Sosial. Bandung: PT.Remaja Rosdakarya.

Suehartono, Irawan. 1995. Metode Penelitian Sosial Suatu Teknik Penelitian BidangKesejahteraan Sosial dan Ilmu Sosial Lainnya. Bandung : PT. Remaja Rosdakarya.

Sugiyono. 2013. Metode Penelitian Kombinasi (mixed methods). Bandung: Alfabeta.

Sumbi, K dan Firdausi, F. 2016. Analisis Pembangunan Berbasis Masyarakat dalam Pengembangan Sumber Daya Masyarakat. JISIP: Jurnal Ilmu Sosial dan Ilmu Politik, 

5(2):
41-45.
Downloaded https://publikasi.unitri.ac.id/index.php/fisip/article/view/239.

from:

Tewu, M.E. 2015. Peranan sumber daya manusia dalam meningkatkan aktivitas Kelompok Tani di Desa Tember. E-journal Acta Diurna, 4(3): 1-9. Downloaded from: https://ejournal.unsrat.ac.id/index.php/actadiurna/article/view/8290.

Wijanarko, Agung Septiawan. 2012. Peran Badan Usaha Milik Desa (BUMDes) Dalam Pemberdayaan Masyarakat Di Desa Pandan Krajan Kec. Kemlagi Kab. Mojokerto (SKRIPSI). Surabaya: Universitas Pembangunan Nasional "Veteran".

Mustanir, A. dan Abadi, P. 2017.Partisipasi Masyarakat Dalam Musyawarah Rencana Pembangunan Di Kelurahan Kanyuara Kecamatan Watang Sidenreng Kabupaten Sidenreng Rappang. Jurnal Politik Profetik, 5(2): 247-261. Downloaded from: http://journal.uin-alauddin.ac.id/index.php/jpp/article/view/4347. 